\title{
Developing Organic Processed Food Entrepreneurial Intention: Study On Women Farmers at Wonokerto, Kecamatan Bantur, Kabupaten Malang
}

\author{
Sri Muljaningsih ${ }^{1,2}$; Soemarno ${ }^{3}$; Djumilah Hadiwidjojo ${ }^{4}$; \\ M. Muslich Mustadjab ${ }^{5}$ \\ ${ }^{1}$ Environmental Science and Technology Graduate Program, Brawijaya University, Indonesia \\ ${ }^{2}$ Department of Economics, Faculty of Economics and Business, Brawijaya University, Indonesia \\ ${ }^{3}$ Department of Soil Science, Faculty of Agriculture, Brawijaya University,Indonesia \\ ${ }^{4}$ Department of Management, Faculty of Economics and Business, Brawijaya University, Indonesia \\ ${ }^{5}$ Department of Agroeconomy, Faculty of Agriculture, Brawijaya University, Indonesia
}

\begin{abstract}
This article investigates organic farming of snake fruit and arrowroot. Those plants are expected to contribute to the farmer household's income improvement. In fact, it gives less contribution to their income. This condition causes those farmers are not interested in this farming business. Consequently, it emerges a problem about how to develop women farmer's entrepreneurial intention at Wonokerto village. In general, this research observed the initial stage entrepreneurship. Therefore, it focused on the entrepreneurial intention. The main objective of this research was analyze the role of women farmers' entrepreneurial intention as the mediator of production factors (entrepreneurship, skill, and naturalland resource) on income improvement of the farmers' household. The analysis tool utilized in this research was path model as the form of advanced regression model. Data collection is conducted by arranging interview and distributing structured questionnaire to 39 respondents whom are women farmers at Wonokerto. The result indicates that entrepreneurial intention is the mediating variable between entrepreneurship and entrepreneurial intention. Thus, the main focus during initial stage of business is to enhance entrepreneurial intention. This research expects if organic snake fruit and arrowroot-based processed food business is able to be implemented, then the existence of Wonokerto's salacca and arrowroot species will be conserved.
\end{abstract}

Keywords: Entrepreneurship, Developing Business Intention, Female Farmer, Organic snake fruit and Arrowroot Based Processed Food, Wonokerto

\section{Introduction}

In Wonokerto Village, as the research location, there is snake fruit (salacca zalacca) plant that is managed by local people from generation to generation. Arrowroot (garut) is also cultivated almost at each of the home yard. Both plants are cultivated naturally and categorized into organic products because those plants are organically cultivated. Green product is agriculture product which grows naturally without synthetic chemical fertilizer [1]. Demand of organic product worldwide recently rapidly advances and is fore casted to be even more rapid in the future with the average growth of 20 percent annually [2]. In 2000, the organic agriculture product trade in the world had achieved US\$ 17.5 billion and possibly will achieve US\$ 100 billion in 2010 [2]. Thus, organic plant emerges opportunities for farmer household income improvement.

Women farmers at Wonokerto commonly have low education level so that they do not dare to take risk for establishing a business since they do not have market accessibility. Thus, it causes a problem on the entrepreneurial intention among women farmers on organic snake fruit and arrowroot-based processed food products. Also, their knowledge about organic snake fruit and arrowroot-processed food's prospect is very limited; yet, they have known organic farming from Science and Technology Diffusion Program of plantlivestock-fish-energy [3].

From the survey research in Wonokerto, it is found that organic snake fruit has not brough significant contribution to the household income improvement among the farmers due to poorly cut-rate price during the harvesting season. The price of arrowroot flour is quite good, but it only contributes to the income improvement whenever there is a holiday of Moslem. Based on this survey, it conducted training on the organic salacca and arrowroot-based processed food product. From the trial on producing organic-processed food product, it provides a quite high economic value-added. Based on this fact, it encourages the development of the entrepreneurial intention on organic snake fruit and arrowroot-based processed food products among women farmers. The business to produce organic-processed food is expected to be able to improve women farmers' income. If those women farmers are able to generate income, then they will increase farmer household's income. 
Therefore, it aims to explore how far the factors that influence women's entrepreneurial intention development are able to improve the income of the farmers' household.

According to Palupi's et.al. [4] research at Turi Village, the price of snake fruit fruit is cheap during harvesting season; and then, there was a snake fruit processing training for those women farmers. The processed food's price enhances 25 percent. Another research, related to women empowerment through entrepreneurship skill training on snake fruit-based product at Desa Umbulmartani, Kecamatan (District) Ngemplak, Kabupaten (Regency) Sleman, showed that the training was able to improve motivation, knowledge, and skill of the women farmers; in turn, it was also expected to be able to improve household income [5]. This condition is also expected to take place on the women farmers at Wonokerto Village, Bantur District, Malang Regency in which snake fruit product is also potential. Next, arrowroot plant's potential, based on Djaafar et.al. [6], is the source of local food that supports food security; thus, this plant also needs nurturing and cultivating. Wonokerto also has arrowroot potential; therefore it needs to develop business intention among women farmers at Wonokerto to make them able to nurture and cultivate both of the plants.

Intention is the mediator between self-efficacy and motivation [7]. Basically, individual intention to be an entrepreneur is affected by innovation behavior which becomes the part of psychological capital [8]. Besides, entrepreneurial intention is also influenced by alertness and financial security [9]. Further, entrepreneurial intention is also influenced by socio-demography, attitude, and contextual factors [10]. Almost all of those perspectives are in the psychology and sociology realms. Douglas and Shepherd [11] highlighted that phenomenon from economics perspective as the decision to become an entrepreneur (entrepreneurial intention) is based on utility preference. It emerges research gap, to combine psychology, sociology, and ecological economics realms that leads the focus of this research to explore entrepreneurial intention which is influenced by production factors (entrepreneurship, skill, and natural/land resource) and chooses women farmers at Wonokerto as the research object.

The description above becomes the foundation of the research imperative. It is aimed to analyze the factors that influence organic processed food entrepreneurial intention that is expected to be able to improve farmer household's income as well as to cultivate snake fruit and arrowroot plants at Wonokerto. Further, the research objectives consist of: 1. Analyzing the factors (entrepreneurship, skill, natural/land resource) that influence organic-processed food entrepreneurial intention by women farmers. 2. Analyzing the role of organicprocessed food entrepreneurial intention by women farmers on farmer household's income. 3. Analyzing entrepreneurial intention as the mediating variable among entrepreneurship, skill, and natural/land resource variables toward farmer household's income.

\section{Literatur Review and Hypothesis Development}

Entrepreneurial intention is the initial stage of a continuous process to establish a business [12]. Entrepreneurial intention recently becomes the main concern to be explored by scholars since it is believed that intention correlates with actual behavior [10]. However, individual's intention to be an entrepreneur is not achieved inevitably; yet, there are several factors that influence it. To develop entrepreneurial intention, it is based on the individual's particular behavior that is motivated by particular expectation to achieve certain result; it is in line with Vroom's Expectancy Theory [8]. Also, individual's behavior is affected by personal interaction and environment factors. Women entrepreneur's innovative behavior depends on the expectation or achievement of their business development [8]. As there is an expectation, it will nurture an intention to be an entrepreneur based on the entrepreneurship. Just like what is mentioned in Theory of Planned Behavior, which explains the correlation between attitude and intention of an individual toward planned action alternatives [13], there is a relationship among entrepreneurial personality, commitment, and self-independent that is proven by the research result in Trengganu agriculture industry [14].

Entrepreneurial intention development on organic-processed food by women farmers is not only to improve their income but also to preserve environment/ecology [15]. It is in line with the basic concept of ecological economics as an interdisciplinary between economics and ecology [16]. In addition, it is also in resemblance with green economy concept that is based on the economy, social, and environment/ecology sustainability of particular ecosystem [17]. Environment economics discusses the external problems that shoud be considered so that it should take the negative effect of production process into account. Therefore, if the production process is already environment-friendly (green-oriented), it reduces pollutant risk and cost. This process produces green food [18]. The example of green food comes from organic farming that is natural and sustainable [3].

To discuss women farmers' entrepreneurial intention on organic snake fruit-based processed food product, it nees to review green cooperation in South Korea called as "Womenlink." That cooperation aims to produce and consume organic (green) food product. The cooperation develops rapidly as the ecological matter has become the focus of attention. The development of "Womenlink" has two main objectives: for social interest and for environmental safety. As the demand on green product increases, it affects the development of 
the women cooperation. This situation emerges opportunity for rural women to be entrepreneurs. It confirms the role of women in rural development [19].

To develop women entrepreneurship on green product, it utilizes a method that involves creativity and marketing through cooperation [20]. Basically, in green entrepreneurship and economic empowerment, the focal point is delivering contribution to enhance rural women's income improvement for the members of "womenlink" in South Korea Republic [21]. The objective guarantees the trust between consumers and producers who expect good quality and safe-food for health. Therefore, organic product business emerges new opportunity for the agriculture sector of developing countries. Next, it can be the source of hope for women (rural) farmers to make an organic-processed food business [22]. Further, according to Lundy [23], organic agriculture system with plant diversification results on the small business opportunity for women. During post-harvest, there is an activity to process the product to have value-added (product innovation) and make marketing effort. For AsiaPasific countries, it needs persistent effort to market the organic products; meanwhile the countries that have been succeeded in the organic food marketing are Japan, China, and Korea [21].

Based on the retail market information, the price of green (organic) product is more expensive than conventional agriculture product [24]. Therefore, organic product is reliable to reduce poverty. It was proven in Bangladesh though the marketing only covered domestic scope due to international certification constraint [22]. Certification becomes a challenge for organic product entrepreneurship [25].

Women's sides that are needed in entrepreneurship are their responsiveness, resilience, and not easy to give up that can be perceived as social capital [8]. Yet, to achieve that condition, rural women, who mostly have low knowledge and education, needs skill enhancement and entrepreneurship as well as marketing network [21]. Research result on rural women entrepreneurs in Greece showed that business success was tightly related to skill, intention, and attitude of the entrepreneur themselves [20].

In Indonesia, more than 70 percent of the women live in rural area; and, 55 percent relies on agriculture as their income source [26]. In Greece, the education level and skill of women farmers were perceived as low, so that it was anticipated by women cooperation development to promote entrepreneur as rural women's career [20]. It occurs in Asia Pacific region as well; ESCAP empowered rural women by promoting women entrepreneur and e-business in cooperation. This approach was aimed to reduce poverty in rural area [21]. The target was green (organic) product niche that was not well-developed yet and provided chance to be organized by rural women through women cooperation establishment [19].

The number of women population in Indonesia is 49 percent from 220 million people; yet, women entrepreneurs/ MSME practitioners are still below 1 percent [27]. IWAPI (Association of Indonesian Women Entrepreneurs) planned to enhance the number of women entrepreneur from 0.24 percent to 2 percent in 2012 by making collaboration with Women Empowerment Ministry [27]. IWAPI endeavored to conduct training program and other program to encourage more women to be entrepreneur [27].

Family takes crucial role in women's life. Most women entrepreneurs get support from their family and friends to manage their business, both during initial stage and development stage of business [28]. It influences women entrepreneurs' emotion. Social relationship also provides significant role on women entrepreneurs; women often feel that they need to communicate with other people who are able to understand and know what they experience. This need can be attained by making social network among women entrepreneurs and arranging regular discussion about several problems that they are facing [28]. Internal motivation for women entrepreneurs is self-fulfillment as an important motivator to start a business. Women entrepreneurs in developed country are motivated by need for achievement [20]. Meanwhile, in developing country, they are motivated by the combination between push and pull factors, such as business provides social contribution to the society [28]. Entrepreneur is an individual or a group of people that organize production factors: natural, human, capital, and skill for production objective [29].

Referring to review of literature, it concludes that entrepreneurial intention is influenced by entrepreneurship, skill, and natural resources. Those three factors in economics theory are called as production factors [30]. Further, business achievement influences income; yet, before establishing a business, it is initialized by behavioral intention of an individual ([13], [9], [31]). Based on that description, then it comes to the conceptual framework that is presented in Figure1.

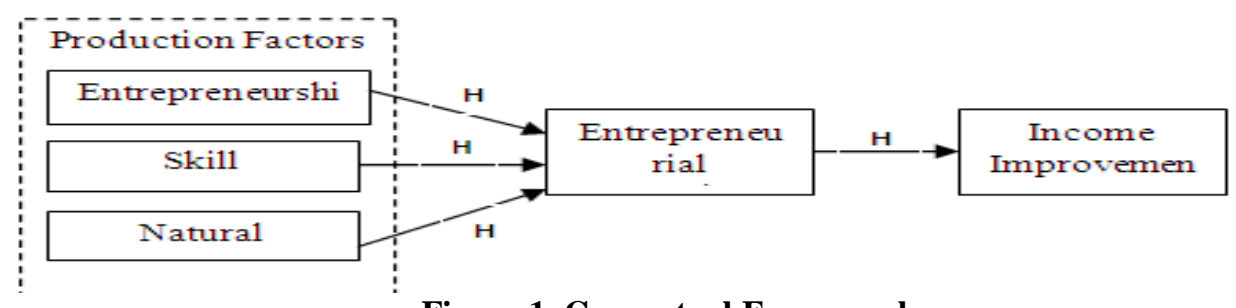

Figure 1. Conceptual Framework 
The conceptual framework becomes the foundation of the hypotheses that are going to be tested in this research:

H1: entrepreneurship significantly and positive affects entrepreneurial intention

H2: skill significantly and positive affects entrepreneurial intention

H3: natural resources significantly and positive affect entrepreneurial intention

H4: entrepreneurial intention significantly and positive affects income improvement

\subsection{Design}

\section{Method}

In the initial stage, this is an experimental action research that involves women farmers. Some of the women farmers get treatment of training/education on organic plant-based (snake fruit and arrowroot) processed food; while the others did not. There are two groups of women farmers; first, those who get a treatment (treatment group) and the second group is who does not get a treatment (control group) [32]. As the initial stage has been done, the next is a survey technique by distributing questionnaires to the respondents.

\subsection{Variable}

Variable is varied symptoms of the research object [33]. This research reviews the role of the treatment of the entrepreneurship behavior on the women farmers. The independent variables consist of production factors including entrepreneurship that is measured by using twenty-four attributes of attitude/behavior indicators. To reveal the dominant factor, it conducts factor analysis; thus, it obtains five factors that represent entrepreneurship attributes such as alertness, optimistic, realistic, persistent, and communicative. Skill variable is measured based on thirteen attributes of respondent's ability. After having factor analysis, it attains three factors such as skill to produce organic-processed food, economy ecology comprehension, and formal education (school). Natural resources variable's indicator is the land size and the plant that is cultivated.

\subsection{Sample}

The sample of this research is women farmer from farmer family who had ever joined Knowledge And Technology Diffusion Program of organic plant-livestock-fish-energy consistently at Wonokerto Village, Malang Regency [3]. The sampling technique is purposive sampling that involves 39 respondents consisting of 19 women who had ever joined education and training program on local organic plant-based processed food and 23 women who never join the training program.

\subsection{Instruments}

The instrument utilized in this research is questionnaire that consists of closed-questions related to the indicators of entrepreneurship, cognitive skill (organic plant comprehension and economic environment/ecology), and psychomotor (practice on organic plant-based processed food production). The questionnaire uses five multiple choices based on Likert's scale from 1 to 5 [34]. Further, the researcher also tries to collect information beyond the questionnaire.

\subsection{Data Analysis}

Data analysis technique employs path analysis model as the development of regression analysis ([35]; [36]). It requires: 1. Linear inter-variables relationship, 2. Causal or one-way relationship, 3. Endogenous variable at least is in interval scale, 4 . Variable measurement is error-free (measurement instrument is valid and reliable), 5. The model that is going to be analyzed based on relevant theory and concept that are able to explain causal relationship among observed variables. This research chooses path analysis based on the reason that the referred theory is Theory of Planned Behavior [13] which states that intention variable is the mediating/intervening variable of a linear path relationship.

To analyze the relationship between local organic plant-based processed food business' factors and income improvement of women farmers mediated by entrepreneurial intention, Ridwan and Kuncoro [37] suggest path analysis model which uses standardized data. The path model of this research results on the following equation:

$$
\begin{aligned}
& Z Y_{1}=p_{11} Z X_{1}+p_{12} Z X_{2}+p_{13} Z X_{3}+\varepsilon_{1} \\
& Z Y_{2}=p_{21} Z Y_{1}+\varepsilon_{2}
\end{aligned}
$$

Where:

$Z X_{1} \quad=$ entrepreneurship variable

$Z X_{\mathbf{2}} \quad=$ skill variable

$Z X_{\mathbf{3}} \quad=$ natural resources variable

$Z Y_{1} \quad=$ entrepreneurial intention variable 


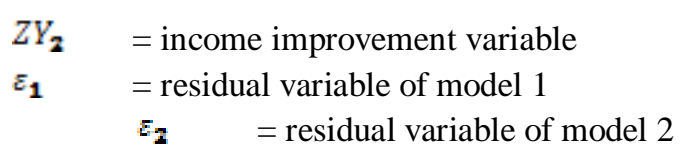

Path model is a path analysis which involves more than one models that construct simultaneous equation system. Besides, the relationship is recursive (one-way) that is based on relevant theories and has linearity assumption

[35]. The path model analysis of this research is presented in Fig.2.

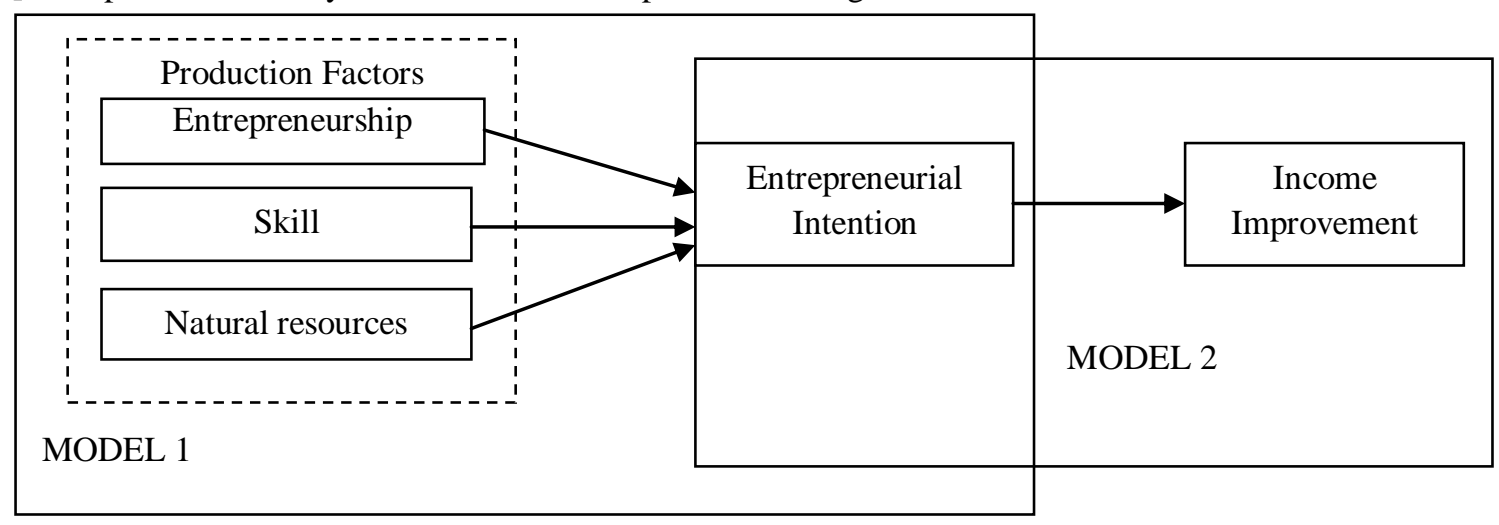

Figure 2. Path Diagram of Production Factors, Entrepreneurial Intention, and Income Improvement

Path analysis is aimed to answer research objectives:

1. The effects of entrepreneurship, skill, and natural resources factors on women farmers' entrepreneurial intention in organic-processed food business. The analysis method uses multiple linear regression as presented in Model 1 (Fig.2).

2. The role of women farmer's entrepreneurial intention on organic-processed toward farmer's household income improvement as presented in Model 2 (Fig.2). The analysis method is multiple regression analysis.

3. Entrepreneurial intention as the mediating variable between production factors and income improvement. First, it arranges the model linearity among entrepreneurship, skill, and natural resources variables toward entrepreneurial intention variable (Fig.3). Next, it examines the linearity model between entrepreneurial intention and income improvement. The analysis result must be linear and significant. Whenever there is a variable that is not significant, it must be eradicated. To investigate path analysis model's validity, it utilizes trimming theory (Fig.4).

\section{Result and Discussion}

It needs to know that before conducting path analysis, we should observe data's reliability and validity. The term of validity test is based on the bivariate correlation value among the scores of each instrument as the total score results on significant conclusion. To conclude the reliability of each instrument, as the Cronbach's Alpha is more than 0.60 then the instrument is reliable [38]. After arranging validity test, the result shows that entrepreneurship and skill variables are found valid. Meanwhile, the Cronbach's Alpha of entrepreneurship and skill are 0.958 and 0.916 respectively implying that both are reliable.

Result and discussion to answer research objective are described as follow:

The regression analysis on Model 1 demonstrates that entrepreneurship, skill, and natural resources (land and plant) are linear with entrepreneurial intention. If linearity occurs, then it fulfills path analysis model. It means that entrepreneurship, skill, and natural resources have recursive relationship. It indicates that there is a direct influence of the exogenous variable (entrepreneurial intention) on the endogenous variables (entrepreneurship, skill, and natural resource). Next, it observes whether the relationship has significant influence or not. The results demonstrates that entrepreneurship provides significant role; whereas, skill and natural resources do not (See Table 1). The role of entrepreneurship $(B=0.553, p=0.000)$ is meaningful on organic-processed food entrepreneurial intention. Therefore, when an individual intends to start a business, then he should consider his entrepreneurship condition. In this research, the dominant aspects of entrepreneurship among women farmers at Wonokerto are: alertness, optimistic, realistic, persistent, and communicative. Alertness is awareness on the profit that they generate; it means that they should calculate the chance to generate profit before starting their business. Optimistic must be attached into the farmers thought since to start a business, they should be sure about the success of the business they want to establish. Realistic attitude of the female farmers in Wonokerto is based on their logic, whether or not the business is feasible to conduct. To 
support the optimistic attitude, it must be encouraged with the persistence to make the business is maintained relentlessly. Next, communicative attitude means that they should be cooperative as among female farmers in Wonokerto should make cooperation between one and the other. It has been conducted when there is a demand on the organic snake fruit and arrowroot- processed food product in relatively huge amount, then they involve their friends or neighbors to fulfill the demand by working together.

The regression analysis result on Model 2 shows that entrepreneurial intention brings significant and linear role $(\mathrm{B}=0.288, p=0.076)$ on the income improvement of the women farmers in Wonokerto. It proves that entrepreneurial intention that results on entrepreneurial behavior to establish organic snake fruit and arrowrootprocessed food product business can improve farmers' household income that comes from women farmers' income. It is linear with Theory of Planned Behavior [13] that intention can be the mediating variable or antecedent of individual's behavior/attitude. In this research, the behavior is business behavior that is able to improve income.

To summarize, the description of the Figure 2 consists of two regression models. The dependent variables are entrepreneurial intention and income improvement for Model 1 and Model 2 respectively. The regression analysis result for the two models is presented in Table 1.

Table 1. Regression Analysis Results of Model 1 and Model 2

\begin{tabular}{|c|c|c|c|c|}
\hline \multirow{2}{*}{ Model } & \multicolumn{2}{|c|}{ Variable } & \multirow{2}{*}{$\begin{array}{l}\text { Standardized Regression } \\
\text { Coefficient (Beta) }\end{array}$} & \multirow{2}{*}{ P-value } \\
\hline & Dependent & Independent & & \\
\hline \multirow{3}{*}{1} & \multirow{3}{*}{ Entrepreneurial Intention } & Entrepreneurship & 0.553 & $0.000 * *$ \\
\hline & & Skill & 0.031 & $0.836^{\mathrm{tn}}$ \\
\hline & & Natural Resource & 0.201 & $0.164^{\mathrm{tn}}$ \\
\hline 2 & Income Improvement & Entrepreneurial Intention & 0.288 & $0.076^{*}$ \\
\hline
\end{tabular}

Description:

$\begin{array}{ll}\text { th } & : \text { not significant } \\ * & : \text { significant at } \alpha=10 \% \\ * * & : \text { significant at } \alpha=5 \%\end{array}$

3.1. The path diagram presented in Fig. 3 is aimed to answer the third research objective.

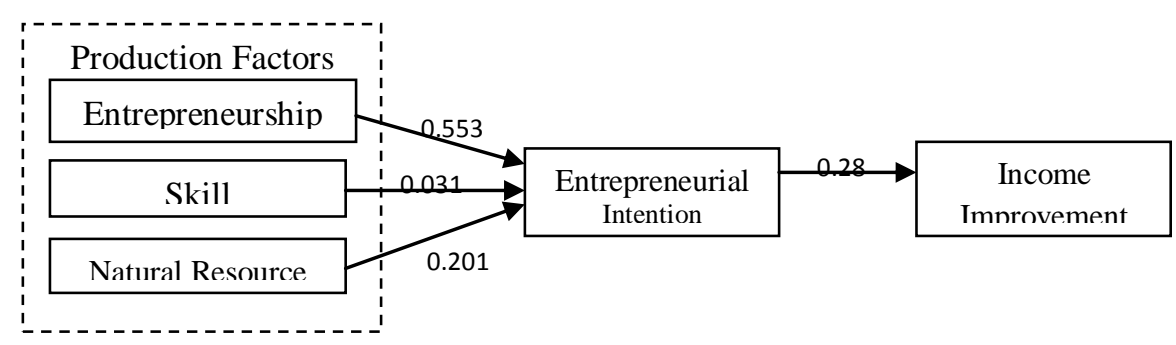

Figure 3. Path Diagram of Production Factors, Entrepreneurial Intention, and Income Improvement based on Standardized Regression Coefficient

The mathematical model of path diagram is

$$
\begin{aligned}
& Z \hat{Y}_{1}=0.553 Z X_{1}+0.031 Z X_{52 I}+0.201 Z X_{3} \\
& Z \hat{Y}_{2}=0.288 Z Y_{1}
\end{aligned}
$$

Based on the equation (3), it can be stated as follow:

a. Every increase of one standardized unit of entrepreneurship, it increases entrepreneurial intention for 0.533 standardized unit.

b. Every increase of one standardized unit of skill, it increases entrepreneurial intention for 0.031 standardized unit.

c. Every increase of one standard deviation of natural resource, it increases entrepreneurial intention for 0.201 standardized unit.

Yet, among the three independent variables, only entrepreneurship variable is significant. In the equation (4), every increase on one standardized unit of entrepreneurial intention increases income for 0.288 standardized unit which is significant. The regression analysis result on Model 1 and Model 2 answer the research hypothesis as presented in the Table 2 below. 


Table 2. Research Hypothesis Testing's Result
\begin{tabular}{|l|l|l|l|l|}
\hline \multicolumn{1}{|c|}{ Variable } & \multicolumn{1}{|c|}{ Beta } & \multicolumn{1}{c|}{ P-value } & \multicolumn{1}{c|}{ Result } \\
\hline Hypothesis 1 & Entrepreneurship & 590 & $.000^{* *}$ & Accepted \\
\hline Hypothesis 2 & Skill & .031 & $.836^{\text {th }}$ & Rejected \\
\hline Hypothesis 3 & Natural Resource & .201 & $.164^{\text {tn }}$ & Rejected \\
\hline Hypothesis 4 & Entrepreneurial Intention & .288 & $.076^{*}$ & Accepted \\
\hline
\end{tabular}

Source: Processed Research Data

Description:

tn : not significant

* $\quad$ : significant at $\alpha=10 \%$

** $\quad$ : significant at $\alpha=5 \%$

Entrepreneurship is qualitative that is translated into quantitative manner through interval scale by using Likert's scale from $1-5$. In this research, entrepreneurship of women farmers at Wonokerto consists of five factors: alertness, optimistic, realistic, persistent, and communicative. The appraisal of entrepreneurship is $5=$ very strong, $4=$ strong, $3=$ average, $2=$ weak, $1=$ very weak. Based on the interview with one of the key respondents, the role of alertness on the income attainment is very strong when they expect high income. Optimistic attitude is measured by the level of assurance that they perceive on organic-processed food business to improve their income. Realistic attitude is based on the logical thinking that the local plants-based (snake fruit and arrowroot) processed food business on their yard or their surrounding environment is feasible to be a source of business. Persistence is measured by their spirit to establish the business. Communicative aspect is determined by their ability to cooperate among the women farmers and with other party by observing the relationship strength with other party such as with marketer.

This part discusses variables that are not significant: skill and natural resource. Based on the fact, after conducting education/training on organic local plants (snake fruit and arrowroot)-based processed food, the women farmers' skill gets enhanced. Related to the natural resource in the form of land size that is planted with snake fruit is, the availability of organic snake fruit is quite sufficient for the basic material of processed food. After an observation, the behavior of the women farmers at Wonokerto is less independent. Self-independence directly correlates with the existing chance; besides, it indirectly correlates with motivation for achievement and with customer relationship as mediated by entrepreneurial commitment [14]. However, they have skill that should be able to motivate them. The available natural resource can be utilized as business opportunity; yet the condition of women farmers who have owned organic snake fruit-based processed food business depend on their customers. It means that they produce based on the demand which implies that they avoid risk. Therefore, alertness toward profit attainment is the dominant factor. They do not want to take any risk to loss. This condition influences on the attitude change of the snake fruit farmers at Wonokerto. As the snake fruit price is very cheap during harvest day, then some of the snake fruit farmers alter their plant from snake fruit to sugarcane plantation. Sugarcane is perceived to be more profitable economically; yet, it is non-organic farming. Therefore, organic snake fruit is more environment-friendly compared to sugarcane that is conventionally cultivated. The interview result after conducting education and training on organic snake fruit-based processed food, those farmers said that if snake fruit is promising as the business opportunity, they would not alter their snake fruit plant to sugarcane. Basically, the function of organic snake fruit plant is not only to preserve environment but also to preserve the icon of South Malang's product which has Swaru snake fruit as the legacy of their forerunner. Arrowroot plant can be cultivated on a home-yard of each population member even they have a narrow land.

The hypothesis test result is discussed on this part. When there is insignificant independent variable, then it should conduct a trimming test [37] to eliminate the insignificant path of the model. The regression analysis result after trimming can be seen in Table 3 .

Table 3. Analysis Result on Model 1 and Model 2 after Trimming

\begin{tabular}{|c|l|l|c|c|}
\hline \multirow{2}{*}{ Model } & \multicolumn{2}{|c|}{ Variable } & $\begin{array}{c}\text { Standardized Regression } \\
\text { Coefficient (Beta) }\end{array}$ & \multirow{2}{*}{ P-value } \\
\cline { 2 - 4 } & \multicolumn{1}{|c|}{ Dependent } & Independent & 0.590 & $0.000^{* *}$ \\
\hline 1 & Entrepreneurial Intention & Entrepreneurship & 0.288 & $0.076^{*}$ \\
\hline 2 & Income Improvement & Entrepreneurial Intention & & 0.28 \\
\hline
\end{tabular}

Source: Processed Research Data

Description:

tn : not significant

* $\quad$ : significant at $\alpha=10 \%$

** : significant at $\alpha=5 \%$ 
Next, the path diagram for the model after trimming is presented in the Figure 4 below:

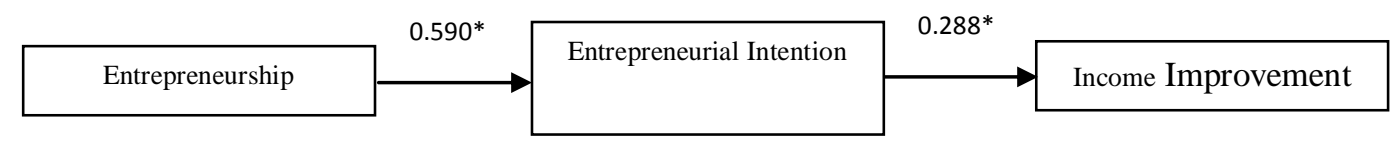

Figure 4. Path Diagram of Entrepreneurship, Entrepreneurial Intention, and Income Improvement after Trimming

The mathematical model of Fig. 4 is

$$
\begin{aligned}
& Z \hat{Y}_{1}=0.590 Z X_{1} \\
& Z \hat{Y}_{2}=0.288 Z Y_{1}
\end{aligned}
$$

Based on the regression analysis result, all of the paths or the independent variables are significant. Therefore, Fig. 4 is the final path diagram of this research. Information implied from the path diagram in statistical language is that entrepreneurship directly affects entrepreneurial intention as much as 0.590 standardized unit; meanwhile, the direct influence of entrepreneurial intention on income improvement is 0.288 standardized unit. Besides, entrepreneurship proved indirect effect on income improvement through entrepreneurial intention that can be observed from the multiplication of path coefficient between entrepreneurship and entrepreneurial intention times path coefficient between entrepreneurial intention and income improvement; thus it is $0.590 \times 0.288=0.170$ standardized unit [37]. Therefore, income improvement can be attained by improving entrepreneurship that is supported by the effort to encourage entrepreneurial intention [5].

General discussion on the women farmers' income improvement is expected to contribute on the farmer household's income improvement at Wonokerto Village. To develop entrepreneurial intention on the snake fruit and arrowroot-based processed food product, it should develop the existing entrepreneurship (alertness, optimistic, realistic, persistent, and communicative) among those women farmers. During the initial stage of business (embryo stage), to achieve the next stage (business implementation), must encourage the entrepreneurial intention. Based on the economics experts, entrepreneurship concept combines production factors: natural resource, labors, materials, and etc. ([39]; [28]) to make value-added or make it more productive by innovation. This is similar with the entrepreneurship theory of Schumpheter and has future prospect [40].

This research analyzes regression relationship between production factor and income improvement mediated by entrepreneurial intention. The term of intention in Theory of Planned Behavior [13] is in resemblance with Vroom's Expectancy theory. As stated by Babalola [8], innovation is affected by psychological capital. Essentially, psychological capital is also interpreted as entrepreneurship. Meanwhile, according to Alias and Zakaria [14], the relationship occurs between entrepreneurial personality and selfindependence through entrepreneurial commitment. Thus, psychology and social realms at the initial stage of business start-up are more dominant. Supported by Bolton and Thomson [41], they expressed that entrepreneur stages, at the initial stage, is called as embryo stage. Based on the Theory of Planned Behavior, intention is the motivating factor that influences individual behavior in achieving his efforts [42]. In sum, the description concludes that intention is the foundation to start a business or do an effort. It is proven in this research since entrepreneurial intention becomes the intervening or mediating variable [38] between entrepreneurship and income improvement.

Women farmers' income can deliver important contribution on the farmer household's income. In line with Chayanov theory, workforce comes from the household itself [43]. Prior research tends to discuss based on the psychological realm so that the recent finding of this research is about making the realm more to the economics perspective by choosing women farmers who cultivate organic plant as the research object. In rural economics theory, it states that land will trigger an effort to invent technology that is able enhance productivity [44]. Thus, if the entrepreneurial intention development is based on the environmental care, then the result will bring impacts not only on the income improvement but also environmental preservation to conserve local snake fruit of Wonokerto variety called as Swaru snake fruit as the icon of South Malang product. Geographically, Wonokerto village is the transportation channel to achieve Balaikambang Beach and Sendang Biru Beach. The organic snake fruit-based processed food product business is expected to enhance tourism of those beaches. Other than snake fruit, this region is fit to cultivate arrowroot that can be the basic material of flour as the source of bread's raw material. If it is developed, it also supports food sustainability.

Basically, entrepreneurial intention on the local and arrowroot-based processed food product emerges expectation and hope on the income improvement for women farmers at Wonokerto. In Bangladesh, it is proven that organic agriculture is able to reduce poverty [22]. In fact, the entrepreneurial intention is an encouraging factor to actualize entrepreneurship as the production factor to produce an output [30]. If the output is successfully produced, it contributes to the income attainment when the output is accepted by market. 
Therefore, women farmer's entrepreneurship on organic plant-based processed food product generates green entrepreneurship thought. It is the originality and finding of this research as entrepreneurial intention on the organic snake fruit and arrowroot-based processed food product can enhance the income of women farmers at Wonokerto.

\section{Conclusion}

\section{Conclusion and Suggestion}

This research has answered the proposed hypotheses. The conclusion is entrepreneurship, skill, and natural resource has linear and positive relationship with entrepreneurial intention. Yet, the factor that brings significant effect is entrepreneurship. It is confirmed that during the embryo stage of business start-up among women farmers at Wonokerto, entrepreneurship provides significant influence; while skill and natural resource variables do not have any significant effect. During the initial stage of business, the key is entrepreneurial intention related to the psychological capital that is entrepreneurship.

Entrepreneurial intention has linear and significant relationship with income improvement. It supported by the belief of the women farmers at Wonokerto that strong intention is helpful to achieve their effort on organic snake fruit and arrowroot-based processed food product business. Snake fruit processed food has higher price that fresh snake fruit itself. Arrowroot flour can be added as the ingredient to produce snake fruit processed food in the form of dodol/jenang (porridge). Thus, it is expected that the business can enhance snake fruit and arrowroot farmer household's income.

Based on the path analysis, it shows linear and significant relationship between entrepreneurship and entrepreneurial intention. Next, entrepreneurial intention also brings linear and significant influence on income improvement. Thus, it is concluded that entrepreneurial intention is the mediating/intervening variable. It implies that entrepreneurship does not directly influence income improvement but should be mediated by entrepreneurial intention.

During qualitative observation on the attitude/behavior of the women farmers at Wonokerto, they have economic motivation; the most dominant on the organic snake fruit and arrowroot-based processed product entrepreneurial intention is income achievement. In fact, they will make the processed food whenever there is a demand on that product. It also reveals that their business is not developed very well related to the marketing effort in other region; thus, they only sell fresh snake fruit to the middlemen (intermediary) who come to their region. It causes the price at the bottom rate.

\section{Suggestion}

This research was conducted during the initial stage of a business so that the focus is on the entrepreneurial intention. Based on the intention, it encourages business behavior (entrepreneurial behavior) to be able to generate or improve income. Further research is suggested to examine the next stage which is after those women farmers become entrepreneur. Other contribution than economics and social, it also preserves the local snake fruit product as the icon of the South Malang product which is able to support coastal and marine tourism development at the surrounding region. Also, arrowroot cultivation effort as the food raw material source for biscuit or cake supports food security.

To develop entrepreneurship and make the intention produces entrepreneurs, those women farmers should be supplemented with entrepreneurship training to be able to arrange business feasibility and plan. It requires government role and related parties to assist this implementation and provide effective support.

\section{Acknowledgement}

The author is much thankful to Mr. Sulistyanto and family as the Head of Rukun Warga (Neighborhood Association) during the implementation of Science an d Technology Diffusion Program at Wonokerto Village (2007-2010) as he has provided information about the outcome of the program that is needed for this research. The gratitude also goes to the Health Department of Malang Regency's staffs and Lily Group as they have assisted in the practice and implementation to produce organic plant-based processed food products.

\section{Reference}

[1] Saragih, Sabastian. 2010. Pertanian Organik, Solusi Hidup Harmoni dan Berkelanjutan, Swadaya, Jakarta.

[2] Ministry of Agriculture .2010. Rancangan Rencana Strategis Direktorat Jenderal Pengolahan dan Pemasaran Hasil Pertanian, Kementrian Pertanian. Jakarta

[3] Agustina, Lily. 2007. Sistem Produksi Sayuran Ternak Ikan Organik Berbasis Pada Limbah Organik. Kerjasama Lembaga Penelitian UB - MenRistek R.I. Malang : LPPM UB

[4] Palupi,Sri. Hamidah,Siti. Purwanti,Sutriyati.2009. Peningkatan produktivitas hasil olahan salak malalui diversifikasi sekunder untuk mendukung pengembangn kawasan agropolitan.inotek : jurnal inovasi dan aplikasi teknologi. Universitas Negeri Yogyakarta. Lembaga Pengabdian kepada Masyarakat. Volume : 13.No : 1Page : 97-112.

[5] Auliana,Rizqie dan Rahmawati,Fitri. 2009. Strategi Pemberdayaan Perempuan Melalui Pelatihan Keterampilan Wirausaha Aneka Olahan Salak di Desa Umbulmartini Kecamatan Ngemplak Kabupaten Sleman. Lembaga Penelitian Universitas Negeri Yogyakarta. 
[6] Djaafar, Titiek F., Sarjiman, dan Pustika,Arlyna B. 2010. Pengembangan Budidaya Tanaman Garut dan Teknologi Penglahannya untuk Mendukung Ketahanan Pangan,Jurnal Litbang Pertanian, 29(1), 2010

[7] Elfving,Jennie; Brannback,Malin; Carsrud,Alan. 2009. Toward A Contextual Model of Entrepreneurial Intentions, http://www.spinger.com/978-1-4419-0442-3

[8] Babalola,S.M,2009, Women Entrepreneurial Innovative Behavior : The Role of Psychological Capital, International Journal of Business and Management . Vol.4,no.11, www.ccsenet.org/journal.html

[9] Gelderen,Marco., Brand,Maryse., Praag,Mirjim., Bodewew,Wynand.,Poutsma,Erik., Gils,Anita.2008.Exlianing entrepreneurial intentions by means of the theory of planned behavior, www. emeraldinsight.com/ 1362-0436.htm

[10] Suharti,Lieli dan Sirine,Hani. 20011, Faktor-Faktor yang Berpengaruh Terhadap Niat Kewirausahaan (Entrepreneurial Intention) (Studi terhadap Mahasiswa Universitas Kristen Satya Wacana, Saltiga), Jurnal Manajemen dan Kewirausahaan Vol.13.N0.2.September 2011: 124-134.

[11] Shepherd,Dean A. And Douglas,Evan J. 2002. Self-employment as a Career Choice: Attitude, Entrepreneurial Intentions, and Utility Maximization. Entrepreneurial Theory and Practice,26(3):81-90.

[12] Lee,S.H. dan Wong,P.K.2004. An Exploratory Study of Technopreneurial Intentions : A Career Anchor Perspective. Journal of Business Venturing.19(1):7-28.

[13] Azjen, Icek and Fishbein,Martin. 1980. Understanding Attitudes and Predicting Social Behavior. USA : Prentice-Hall.

[14] Alias,Muhammad dan Zakaria,Azemi. 2011. An Inter-Relatioshipof Entrepreneurial Personality,Commitment and Self-Independent in A Terengganu Agriculture Industry, International Journal of Business and Social Science.Vol 2 No.23.

[15] Managi,Shunsuke.2007. Ecological Economics - Research Treands "Ecological Productivity: Definition and Applications",Nova Science Publishers, Inc.

[16] Common,Michael dan Stagl,Sigrid .2005. Ecological Economics, An Introduction, Cambridge University, Press.UK. www.elsevier.com/locate/foodpol. website: www.cambridge.org/common

[17] UNEP. 2009. United National Environment Program: The Green Economy Initiative is one of the nine UN- wide Joint Crisis Initiatives, the UN System's Chief Executives Board.

[18] Field and Olewiler.2002. Environmental Economics, McGraw-Hill, Canada.

[19] Sanyang,S.E, dan Huang,W-C .2008. Green Cooperatives : A Strategic Approch Developing Women's Entrepreneurship in the Asian and Pacific Region, World Journal of Agricultural Sciences 4(6):674-683,2008, IDOSI Publications.

[20] Petridou E. And Glaveli N. 2008. Rural women entrepreneurship within co-operative : training suport, Gender in Management An International Journal, Vol.23 No.4,2008.pp 362-277 .Emerald Group Publishing Limited.

[21] UN.2007. Developing Women's Entrepreneurship and E-Business in Green Cooperatives in The Asian and Pacific Region, ESCAP, New York.

[22] Sarker,Md.Asaduzzaman and Itohara,Yoshihito. 2008. Organic and Poverty Elimination : A suggested Model For Bangladesh, Journal of Organic System-Vol.3 No.1, diunduh dari : www.orgnic-system.org. Desember 2010.

[23] Lundy, Mark .2002. Rural Agro-enterprises, Value Adding and Poverty Reduction: A Territorial Orientation for Rural Business Development (RBD). Florida.

[24] Poulston,J.and Kwong Yiu,AY.2011. Profit or Principles : Why do restaurant serve organic food ?, International Journal of Hospitality Management 30(2011)184-191straint, and Interventions.

[25] Padel S.,Rocklinsberg H.,Schmid O..2009. The implementation of organic principles and values in the European Regulation for organic food, Food Policy34(2009)245-251. www.elsevier.com/locate/foodpol. .

[26] Elizabeth,R.2008.Peran Ganda Wanita Tani dalam Mencapai Ketahanan Pangan Rumah Tangga di Pedesaan, Iptek Tanaman Pangan Vol.3 No.1

[27] Tambunan,Tulus.T.H..2012. Women Entrepneurship in Indonesia : Determinants, Motivations and Constraints, Center for Industry, SME and Business Competition Studies, Trisakti University, Jakarta-Indonesia

[28] Alam,S.S.2011. An Empirical Study of Success Factors of Women Entrepreneurs in Southern Region in Malaysia. International Journal of Economics and Finance Vol.3,No.2.

[29] Alma, Buchari. 2009. Kewirausahaan Untuk Mahasiswa dan Umum. Bandung: Alfabeta.

[30] Samoelson dan Nordhaus. 1996. Mikro Ekonomi, Erlangga, Jakarta

[31] Michaelidou,Nina dan Hassan,Lousie M..2010.Modeling the factors affecting rural consumers' purchase of organic and free-range produce : A case study of consumers' from the Island of Arran in Scotland,UK, journal homepage : www.elsevier.com/locate/food pol

[32] Sekaran,Umar.1992. Research Methode for Business : A Skill-Building Approach, John Wiley \& Sons, Inc, Singapore.

[33] Arikunto, Suharsimi. 2002. Prosedur Penelitian, Suatu Pendekatan Praktek. Jakarta: Rhineka Cipta.

[34] Sugiyono . 2007. Metode Penelitian Pendidikan (Pendekatan Kuantitatif, Kualitatif, dan R \& D). Bandung: Alfabeta.

[35] Wright,S.1960. Path Coeficient and Path Regression :alternative or complementary concepts.Journal of the biometrics society Vol.16 no 14 pp 189-202.

[36] Hair,J.R,Black,W.J.,Babin,Aderson,R.E.and Tatham,R.L.2009.Multivariate Data Analysis,Prentice Hall Inc.New Jersey.

[37] Riduwan dan Kuncoro,E.A..2011. Cara Menggunakan dan Memaknai Path Analysis, Alfabeta,Bandung

[38] Ghozali,Imam.2006. Aplikasi Analisis Multivariate dengan Program SPSS, Badan Penerbit-Undip.

[39] Suryana .2008. Kewirausahaan,Pedoman Praktis :Kiat dan Proses Menuju Sukses, Salemba Empat,Jakarta.

[40] Wood,J.Stuart.2005. Development and Present State of The Theory of Entrepreneurship in Product and Asset Markets by Knight,Hayek,Schumpeter,Mises, Kirzner,Shackle,and Lachmann. Austrian Concepts and the Mainstream .Austrian Scholars Conference 2005 Saturday, March 19, 2005, 3:15 - 4:45 PM.

[41] Bolton,Bill and Thomson,John. 2004. "Temperament,Technique".Second edition, Elsevier Butterworth Heinemann,Amsterdam.

[42] Hisrich, Robert D ; Peter,Michael P.,Shepherd,DeanA. .2008. Entrepreneurship, McGraw - Hill

[43] Bernstei,Henry.2009. V.I. Lenin and A.V.Chayanov:Looking back,Looking forward, Journal of Peasant Studies, Vol. 36, No. 1, January 2009, 55-81, London, UK. http://www.informaworld.com/ smpp/title content= t713673200

[44] Ellis,Frank. 1989. Peasant Economics, Market and prices in less development countries, Cambridge University Press, Cambrige,New York. 